\title{
Laron syndrome: A case report
}

\author{
K.S.H de Silva ${ }^{1}$, Y.A. Arundathi Jayasena ${ }^{2}$ \\ Sri Lanka Journal of Child Health, 2011; 40(4): 179-180
}

(Key words: Laron syndrome; GH insensitivity; low IGF-1; postnatal growth failure; Sri Lankan child)

\section{Introduction}

Laron syndrome is due to growth hormone insensitivity and is clinically characterized by postnatal growth failure and very low serum levels of insulin like growth factor 1 (IGF-I) despite increased secretion of growth hormone $(\mathrm{GH})$. This mainly autosomal recessive syndrome is clinically indistinguishable from isolated $\mathrm{GH}$ deficiency (IGHD). It was first reported by Laron and colleagues in 1966 in 3 Israeli Jewish siblings with hypoglycaemia and clinical phenotype of GHD. It has been reported from the Mediterranean, mideastern region and Indian subcontinent ${ }^{1,2}$ and has been described in a Sri Lankan child who lived in Switzerland ${ }^{3}$. We report a three year old girl with Laron syndrome diagnosed in Sri Lanka.

\section{Case report}

A three year and four month old girl, the only child of first cousin parents with average height, was referred for evaluation of short stature. She was born following an elective caesarean section and weighed $3.35 \mathrm{~kg}$ at birth. Her length at birth had not been recorded. She was exclusively breastfed for 6 months and was growing along the birth centile. Thereafter, weight faltering was noted which was attributed to inadequate weaning. Her mother had also noted that her linear growth was inadequate from approximately nine months of age. Apart from a mild delay in her gross motor milestones, her development was normal and the first tooth had erupted at seven months of age.

Examination revealed a cheerful child with midfacial hypoplasia and subtle dysmorphism with frontal prominence, saddle nose, flat nasal bridge and a high pitched voice. She weighed $6.8 \mathrm{~kg}$ and her length was $72 \mathrm{~cm}$, both of which were well below the third centile. Her occipito-frontal circumference (OFC) was $43 \mathrm{~cm}$ which was just

\footnotetext{
${ }^{1}$ Senior Lecturer, Department of Paediatrics, Faculty of Medicine, Colombo, ${ }^{2}$ Registrar in Paediatrics, Lady Ridgeway Hospital, Colombo
}

(Received on 19 November 2010: Accepted on 17 December 2010) below the third centile. Her length was also well below the mid parental height range. Her upper segment: lower segment ratio was 1.03:1 and body mass index was $13.6 \mathrm{~kg} / \mathrm{m}^{2}$. There was no Turner phenotype and her physical examination was unremarkable.

Her basic haematological, renal and liver function tests were normal as were her thyroid function tests and $0800 \mathrm{~h}$ serum cortisol level and serum calcium level. Skeletal survey excluded a skeletal dysplasia. Her bone age was 24 months at a chronological age of 3 years and 2 months. Pituitary gland was normal on neuro-imaging. Buccal smear was positive for Barr bodies. She demonstrated fasting hypoglycaemia and severe symptomatic hypoglycaemia at $120 \mathrm{~min}$ and $150 \mathrm{~min}$ during the glucagon stimulation test. All growth hormone levels were $>40 \mathrm{ng} / \mathrm{ml}$ and the basal cortisol was $646 \mathrm{nmol} / 1$. We did an IGF-1 level which was very low at $<25 \mathrm{ng} / \mathrm{ml}$ (49-289). Thus a diagnosis of growth hormone resistance was made but insulinlike growth factor binding protein-3 (IGF-BP3) or genetic studies could not be done.

\section{Discussion}

Children with Laron syndrome clinically resemble isolated growth hormone deficiency Type 1A. Growth hormone receptor is encoded by a single gene located on the short arm of chromosome 5 (5p 13-p12). Laron syndrome is due to a variety of homozygous point mutations in the growth hormone receptor gene ${ }^{4}$. The growth hormone receptor has an extracellular growth hormone binding domain, a transmembrane domain and an intracellular signalling domain. Mutations in the extracellular domain interfere with binding of growth hormone resulting in Laron syndrome ${ }^{5}$. In this condition IGF-1 and IGF-BP3 are markedly reduced despite normal or elevated serum levels of growth hormone ${ }^{1}$ and there is unresponsiveness to endogenous and exogenous GH.

Clinical presentation is with extreme short stature with length more than 4SD below the mean by 1 year of age ${ }^{5}$. Pregnancy is uncomplicated and birth weight and length are usually within the reference range. After infancy the length/height deficit ranges between 4 and 10 height SDS below the median for 
normal length/height ${ }^{6}$. Skeletal maturation is retarded starting in utero and continues throughout life.

Protruding forehead, saddle nose, sunset appearance of eyes and a high pitched voice, small hands and feet (acromicria) and short limbs with upper segment: lower segment ratio more than 1, which are typical features of Laron syndrome ${ }^{6}$ were seen in our patient. Motor development in infancy is delayed as was seen in our patient. In Laron syndrome puberty is delayed without the typical growth spurt but both sexes reach full sexual development with normal fertility ${ }^{7}$.

Treatment with recombinant IGF-I improves growth rate $(8 \mathrm{~cm}$ in the first year and $4-5 \mathrm{~cm}$ in the following years) and normalizes the biochemical abnormalities ${ }^{8}$. The best response is seen in very young patients and treatment should therefore be started as early as possible $e^{3,9}$. Intermittent therapy is shown to be equally cost effective as daily treatment ${ }^{3}$. There is an inverse relationship between age at start of rhIGF-I treatment and total height gain in patients treated for more than 4 years ${ }^{9}$.

IGF-1 is not licensed to be used in Sri Lanka, but it is possible to give it on a case by case basis. Our patient was diagnosed at 3 years and 4 months of age and would have shown a good response to treatment. However, the parents could not afford the extremely high cost of therapy. Without treatment her adult height would be approximately $108-136 \mathrm{~cm}^{8}$. She will need close monitoring for hypoglycaemia, obstructive sleep apnoea, obesity, hypercholesterolemia and diabetes mellitus ${ }^{1}$ and long term psychological support.

\section{References}

1. Laron Z. Growth hormone insensitivity (Laron syndrome). Reviews in Endocrine and Metabolic Disorders 2002; 3: 347-55. http://dx.doi.org/10.1023/A:1020905725012

2. Chakrabothy PP. Basu AK. Mandal SK. Dipanjan B. Laron's syndrome in two siblings. Indian Journal of Pediatrics. 2007; 74: 870-1. http://dx.doi.org/10.1007/s12098-007-0159-y
3. Besson AL, Souzan S, Andre E, et al. Primary GH insensitivity (Laron syndrome) caused by a novel $4 \mathrm{~kb}$ deletion encompassing exon 5 of the GH receptor gene: effect of intermittent long-term treatment with recombinant human IGF-I. European Journal of Endocrinology 2004; 150: 635-42. http://dx.doi.org/10.1530/eje.0.1500635

4. Lopez-Bermejo A, Buckway CK, Rosenfeld RG. Genetic defects of the growth ormoneinsulin-like growth factor axis. Trends in Endocrinology and Metabolism 2000; 11: 3949.

http://dx.doi.org/10.1016/S10432760(99)00226-X

5. Kliegman RM, Behrman RE, Jenson HB, Stanton BF. Growth hormone insensitivity. Nelson's Textbook of Pediatrics, $18^{\text {th }}$ edition, 2: 2296-7.

6. Arad I, Laron Z. Standards for upper/lower body segment/sitting height-subischial leg length, from birth to 18 years in girls and boys. In: Proc 1st International Congress of Auxology, Rome, Italy, 1977 Milan, Centro Auxologia Italiano di Piancavallo 1979; 15964.

7. Laron Z, Sarel R, Pertzelan A. Puberty in Laron-type dwarfism. European Journal of Pediatrics 1980; 134:79-83. http://dx.doi.org/10.1007/BF00442408

8. Laron Z. Consequences of not treating children with Laron syndrome (primary growth hormone insensitivity). Journal of Pediatric Endocrinology and Metabolism 2001; 14(Suppl. 5):1243-8.

9. Ranke MB, Savage MO, Chatelain PG et al. Long-term treatment of growth hormone insensitivity syndrome with IGF-I. Results of the European Multicentre study. Hormone Research 1999; 51: 128-34 http://dx.doi.org/10.1159/000023345 